\title{
The comparison of classical weaving and laser technology in denim fabric's design
}

DOI: $10.35530 / I T .072 .04 .1790$

\section{ABSTRACT - REZUMAT}

The comparison of classical weaving and laser technology in denim fabric's design

Denim fabrics became a preferred product by many people, because of especially being a symbol of comfort. In this study, the aesthetic and physical design of denim fabrics were carried out. It was aimed to compare the surface designs and structural parameters of denim fabrics obtained by weaving and laser technologies. Besides the design steps of weaving and laser technologies were explained and compared. Twelve denim fabrics having different surface designs were obtained with the intersection of indigo dyed warp and non-dyed weft yarns based on the theme of "contrast" by using derivatives of twill weave. Besides, these surface patterns were applied to classical denim fabrics by laser technology. The surface properties of denim fabrics produced by weaving technology were different for each surface designs because of different floatings. However, weaving is a time-consuming method and the design steps are more complicated. On the other hand, surface patterns of fabrics obtained by laser technology were found similar to woven ones and it had advantages as having greater design capacity, being a simpler, faster and eco-friendly method.

Keywords: denim fabric, design, laser technology, weaving

\section{Comparația între tehnologia clasică de țesere și tehnologia laser în proiectarea țesăturii din denim}

Tesăturile din denim sunt preferate de către multe persoane, datorită faptului că sunt în special un simbol al confortului. în acest studiu, s-a realizat proiectarea estetică și fizică a țesăturilor din denim. S-a urmărit compararea designului suprafeței și a parametrilor structurali ai țesăturilor din denim obținute prin tehnologia de țesere și tehnologia laser. Pe lângă etapele proiectării de țesere, au fost explicate și comparate și tehnologiile laser. Douăsprezece țesături din denim având design de suprafață diferit au fost obținute prin intersectarea firelor de urzeală vopsite indigo și a firelor de bătătură nevopsite pe baza temei "contrastului", prin utilizarea derivaților de legătură diagonal. În plus, acest design de suprafață a fost aplicat țesăturilor clasice din denim prin tehnologia laser. Proprietățile de suprafață ale țesăturilor din denim produse prin tehnologia de țesere clasică au fost diferite pentru fiecare design de suprafață, din cauza flotărilor diferite. Cu toate acestea, țeserea este o metodă care consumă mult timp, iar etapele de proiectare sunt complicate. Pe de altă parte, designul de suprafață al țesăturilor obținute prin tehnologia laser a fost similar cu a celor țesute și avantajul acestora a fost capacitatea de proiectare extinsă, fiind o metodă mai simplă, mai rapidă și ecologică.

Cuvinte-cheie: țesătură denim, design, tehnologie laser, ţesere

\section{INTRODUCTION}

Denim products preferred by miners in the United States at the beginning due to their strength became globally recognized clothes with their comfortable nature. Denim products are in great demand in markets around the world. Classical denim fabric is a cotton woven fabric produced by using indigo dyed warp yarns and non-dyed weft yarns, especially in 2/1 or $3 / 1$ twill weave types. Today, various kinds of denim fabrics are produced and used in different clothes (blue-jeans, skirts, dress, etc.), accessories (shoe, bag, etc.) and home textiles (upholstery, curtain, etc.) by the influence of fashion.

Denim fabrics are generally produced by using cotton yarns. However, when looking at the structural design of denim fabrics it was observed that different types of fabrics produced by using different raw materials (such as polyester, linen, bamboo, lyocell, modal, etc.). The variation in the usage of materials enables denim to have a wide-ranging assortment of fabrics [1]. In the past few years, elastane-containing denim fabric has seen an exponential increase in demand due to its unique weave structure and surface design. Denim is generally woven by using open-end and carded ring-spun yarns produced in $\mathrm{Ne} 5$ and $\mathrm{Ne} 17$ number range. Warps are usually thinner than wefts and have more twist in order to ensure strength during weaving [2]. The effect of different yarn spinning technologies such as ring, compact, sirospun, Open-End (OE) rotor and vortex were studied to investigate the performance properties of denim fabrics. It was observed that although they had a similar fading view after the abrasion test, the breaking strength, tear strength, abrasion resistance, stiffness and stretch properties of denim fabric produced by different yarn technologies were different [3]. In fabric construction, the warp setting designed higher than the weft setting. $2 / 2$ twill and plain weaves are also used [4]. The mass per unit area of fabric depends on the usage area of the product. 
Denim fabrics were classified as lightweight, midweight and heavyweight fabrics. Lightweight fabrics are under $12 \mathrm{oz}$, mid-weight fabrics are between 12-16 oz and heavyweights are over $16 \mathrm{oz}$.

The production processes of denim are different from classical woven fabrics because of the indigo dyeing process. Different colour of denim fabric is produced but most preferred one is indigo. In the manufacturing of denim, the warp yarns are dyed by either rope or slasher dyeing methods. The indigo dyeing process is actualized by the oxidation phenomenon of warp yarns passed through consecutive dying vessels [5]. Indigo never penetrates completely into the yarn, so dyeing of the yarn is repeated on more than one vessel. The colour of indigo is changing over time due to the low fastness of the friction. Denim fabrics having a low washing fastness, medium-light fastness and low dry friction fastness are produced thanks to indigo dying. The fact that denim fabrics have friction fastness has always been regarded as a disadvantage yet, as time passed, this trait has become a desired aspect of the denim design. Thus, the colour and friction fastness in denim fabrics have been looked at in a positive light as the colours wearing off helps add a new fashionable dimension to the fabric. Products made from this fabric are subjected to various physical and chemical ageing methods to create an outdated, fading and worn-out effect on the product.

Industrial denim finishing treatments include various dry and wet processes. Dry processes are sanding, sandblasting, brushing, whiskering and destroying treatments. Wet processes include prewashing, rinsing, stone washing, sand-washing, bleaching, enzyme washing, stone washing with enzymes, permanganate spray, resin wash, desizing, and other special finishes [6-12]. Structural properties and finishing operations of denim affect the performance properties of the end product [12]. The influence of different washing techniques on fabric properties such as structural characteristics, shrinkage, air permeability, bending rigidity, breaking force and elongation, shear rigidity was investigated and the results of washing techniques were compared. It was observed that silicone softening has the most effect on denim properties such as shear, bending [6]. The special finishing processes such as wax, soft resin, leather, and spide finish decrease the breaking force and change the spectral characteristics of denim, but result in attractive patterns [7]. It is noted that using enzymes in denim finishing have advantages comparing different conventional denim treatments. These are being efficient, biodegradability, easy control, acting on a specific substrate exclusively and being an environmentally-friendly process [7-8]. The effect of enzymes on performance properties (tensile, colour) of denim fabrics and products were investigated to find optimum denim finishing conditions by using different enzyme combinations [8-10] and process parameters [11]. Enzyme washing recommended as an optimum treatment than other conventional methods creating less deformation on the product [12].
The denim finishing processes using conventional treatments cause pollution of the environment. Recently, the laser engraving treatment applied to denim products as an alternative to conventional technologies. The denim washing processes that were manually carried out depending on manpower (sanding, ageing fading and spraying, etc.) can be performed using laser and robot systems. The principle of the laser engraving process is to remove various amounts of the surface fibres and dye molecules from the fabric surface. This cause change in the colour quality values of denim fabric [13]. It is possible to achieve fading, worn-out effect or different surface designs by laser technology without using water and chemical agents [13-16]. Being a dry process make laser-engraving treatment a low cost [15] and an environment-friendly method [16-18]. Other advantages of laser engraving over traditional methods are denoted as laser technology has higher working speed [18]. It reduces waste and labour. It saves time, energy, water and chemicals [13-19]. Controlled treatment with a lower risk of product damage can be applied by laser process [13, 17, 19]. Laser engraving treatment creates different surface designs in a short time with various size and intensity $[13,17,21]$. The patterns can be applied surface of the product by using graphic design and CAD-CAM systems to increase the variety, accuracy, repeatability and standardization of design [13, 17-20]. To summarize, the application of laser engraving to denim is preferred due to being accuracy, efficiency, simplicity, automation, low cost, desired variety and environmentally friendly method.

There are two types of commercially used laser technology as solid-based (wavelength of $1 \mu \mathrm{m}$ ) and gasbased (wavelength of $10 \mu \mathrm{m}$ ) [13]. The $\mathrm{CO}_{2}$ laser is the most preferred one as an effective method for the treatment of denim surface in a short time. In laser technology, a pair of high-speed mirrors controlled by a computer system drives the laser beam on the product and the beam fade the denim surface according to design. Any image created graphically can be transferred on a denim surface by a suitable laser process. Fading phenomena occurs as a result of the decomposition of the dye and removal of the decomposed dye by evaporation. Various fading effects can be created by changing the parameters of the laser. Some of the important laser parameters defining the degree of fading are the wavelength, power density, and pulse width, etc. $[13,19]$.

Researchers investigated the effect of laser parameters on some structural and performance properties of denim fabrics [13-16, 21-23]. Laser and different treatment methods were also compared [15, 18, 21]. The effects of laser power intensity on colour change and surface properties of denim samples were investigated by applying various combinations of resolution and pixel time. It is noted that the prolonged pixel time and high resolution increases the laser power energy and the high laser power density increase the fading effect $[13,15,23]$. Changing speed, power, 
step parameters creates different effects. For instance, the increase in power increased colour change. Increasing laser speed decreased colour change. On the other hand, the step had the lowest impact on colour change [22]. In another study, different wavelength and power density of laser are applied to denim optimum parameters were defined $[14,24]$. Various combination of laser parameters such as output power, speed of engraving, frequency, etc. was changed and an enzymatic process was applied after laser treatment [16]. The fading effect after both laser and enzymatic treatments were different according to laser parameters. Laser treatment was also compared with manual fading processes [18], sand-blasting and washing processes [21], and cellulose treatment [15]. In all studies, the colour change was measured by using a spectrophotometer and morphological analysis were done by scanning electron microscope [13-15, 20, 22, 23]. Increasing laser intensity increase colour loss on denim [13, 18, $21,23]$. The colour levelness was found independent of the direction of laser irradiation [23]. The colour change in warp and weft direction was also found different [22]. The morphology of the fibre was also different after treated with various laser parameters. It is noted that the increase in power density creates a sponge-like structure $[13,15,23]$. The structural (weight and thickness), strength properties after laser treatment were also changed after fading treatments especially laser process having higher intensity [18, $21,24]$. The strength of fabrics treated by laser technology was found greater than manual ones [18]. The effect of two different yarns produced with different spinning technologies (torque-free ring-spun and conventional ring-spun) on laser treatment of denim was investigated and colour fading of torque-free ring-spun yarn is better after laser treatment [15]. In another study, the same design was applied to denim product by laser treatment and pigment printing. The tensile strength of fabrics was similar for both methods. Comparing with printing technology the laser technology was defined as a faster method [25]. In previous studies, it is noted that with careful selection and control of laser parameters, different degrees of colour fading could be achieved without important strength lose and any damage. [13-15, 18, 21-24] Innovation is very important in the denim market. In this study, the surface patterns of fabrics produced by weaving and laser technologies were compared. There are many studies about the comparison of laser and other classical denim treatment methods. This is the first study that compared the appearance and structural parameters of denim fabrics obtained by weaving and laser technologies. Firstly, the aesthetic design studies were carried out according to the defined theme. Surface patterns of denim were formed by using derivatives of twill weave. Then, the physical designs of the fabrics were studied and the structural properties of fabrics were defined by calculations. Some constraints about the production were also considered during physical design studies and the structural properties were rearranged according to these limitations. Designed fabrics were woven by a sample loom. Besides, created patterns were applied on the surface of a classical denim fabric woven with $3 / 1$ twill weave by using laser technology. The structural properties and surface patterns obtained from these two technologies were compared.

\section{MATERIAL AND METHOD}

\section{Aesthetic design}

In this study, a new perspective on the denim fabric design was brought. When designing on a denim fabric it is common to use techniques of denim finishing processes. Unlike classic denim production, it is aimed to design different surface effects and these surface designs were applied by both weaving and laser technology.

The intersections of indigo dyed warp yarns and nondyed weft yarns create a clear-cut visual difference between the two sides of the fabric. The contrast property of denim fabric is selected as the theme of this aesthetic design study. Contrast is a concept that is encountered every day, but ironically, it is accepted as something ordinary that we see in our lives. Examples of contrast are; night-day, hot-cold, blackwhite, old-young. As can be seen from examples, although the contrast between the two things that create contrast seems to separate them, their differences complement each other to form the whole. Increasing contrast effect at any application increase the attention of the viewer and adds an aspect of excitement to the art. Contrast happens when two different things with different characteristics are brought to the same application. For instance, a light colour on a dark textile surface or vice versa.

Surface designs were formed to increase the colour contrast created by the use of different coloured warp and weft yarns. In classical denim fabrics, warp yarns are dominant on the surface of the fabric. In this study, twelve different surface patterns were designed by using derivatives of twill weave in order to create the concept of contrast by weaving technology. These derivative weaves are; shaded, zigzag, diamond, herringbone, and wavy twills. The unit weave reports are given in figure 1. As seen in figure 1, the contrast effect is achieved on the surface by using long warp or weft yarn floatings having light and dark colour in the weave unit.

Designed weave units were also applied on the surface of a classical denim fabric by laser technology. The surface designs were provided by the repetition of each weave unit in both warp and weft directions as seen in figure 2 . These screen views were transferred to the laser machine and the process was carried out.

\section{Physical design}

The structural properties of fabric such as yarn linear density, settings and mass per unit area should be defined in order to produce the designed fabric. 


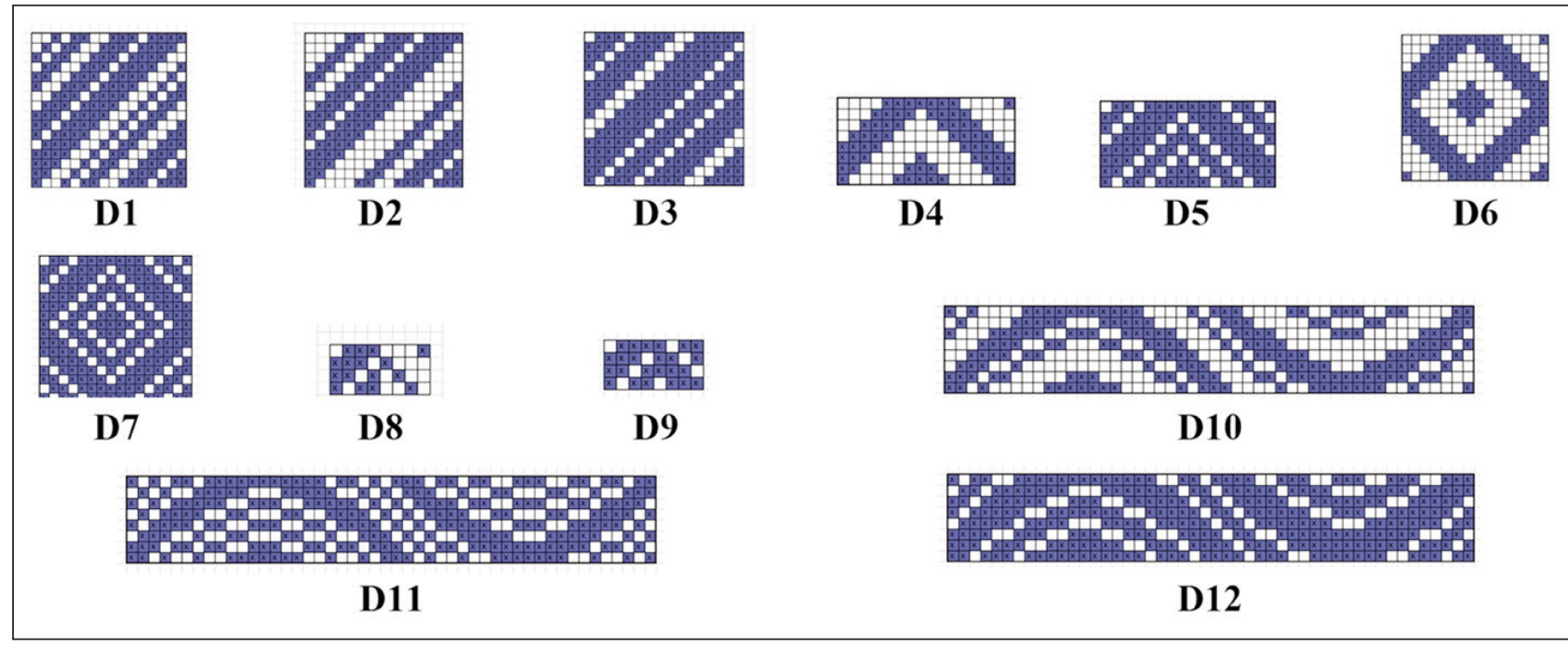

Fig. 1. Unit weave reports of surface designs

$100 \%$ cotton-carded yarns were used in warp and weft direction. The linear density of warp and weft yarns was 30 tex and 37 tex, respectively. The warps were indigo dyed and wefts were non-dyed cotton yarns. Theoretical warp and weft settings of finished fabrics were calculated according to Ashenhurst's formula given in equation 1 [26]. In this equation, $S$ is setting, $k$ is crimp factor, $F_{w}$ is weave factor, $K$ is yarn coefficient according to yarn technology ( $K$ is 8.3 for cotton yarns), $N$ is yarn count in metric system ( $\mathrm{Nm})$. The weave factor $\left(F_{w}\right)$ was calculated for each design according to the weave unit by using equation 2 . In equation $2, y$ is the number of yarns in the weave unit and $i$ is the number of intersections in the weave unit. The weave factor was calculated for both warp and weft direction. In this study, the crimp factor, which was the ratio of un-crimped yarn length to crimped yarn length, was estimated as being 1.05 for both weft and warp direction. The estimated mass per unit area of finished fabric ( $w)$ was calculated depending on yarn count, setting and crimp factor by using equation 3 . The subscripts 1 and 2 were used for warp and weft directions, respectively. Settings of fabrics at loomstate were also calculated theoretically for each design by using equation 4 . Here, $S_{L}$ is the loom setting. The theoretical warp loom settings were calculated at the range of 32-39 thread/cm depending on weave types. The

industuำ textillă mean value of the theoretical loom setting was found as 34 threads/cm along the warp direction in order to produce all fabric types with the same warp.

$$
\begin{gathered}
S=k F_{w} K \sqrt{N} \\
F_{w}=\frac{y}{y+i} \\
W=\frac{100 k_{1} S_{1}}{N_{1}}+\frac{100 k_{2} S_{2}}{N_{2}}- \\
S_{L}=F_{w} K \sqrt{ } N
\end{gathered}
$$

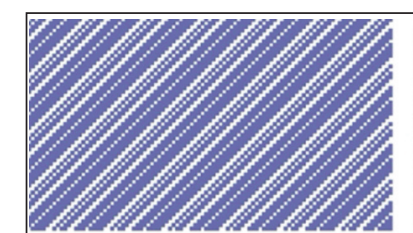

D1

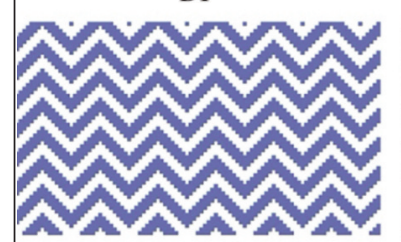

D4

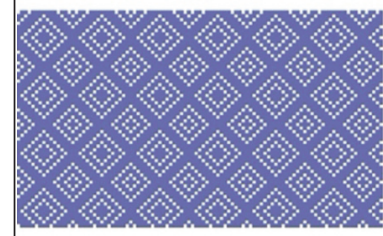

D7

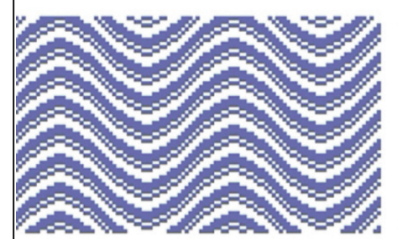

D10

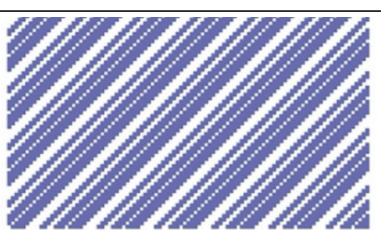

D2

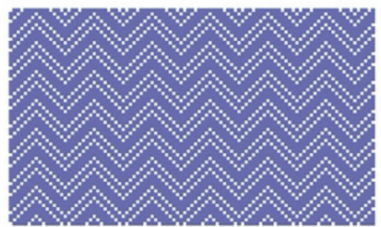

D5

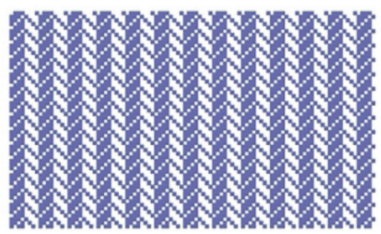

D8

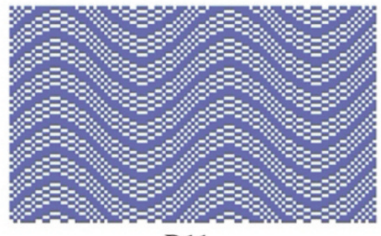

D11

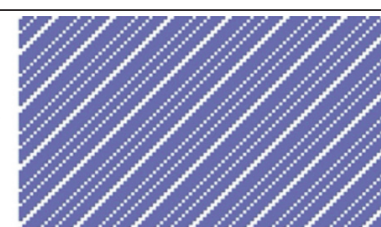

D3

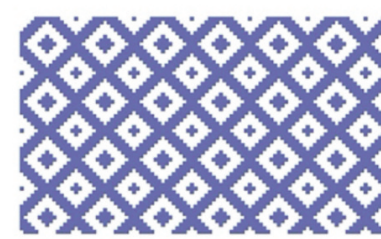

D6

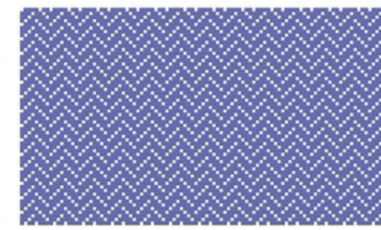

D9

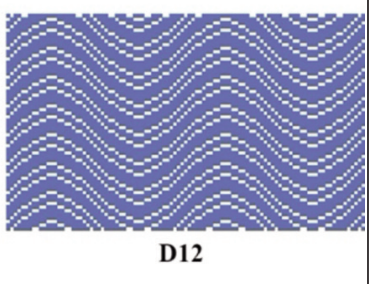

D12

Fig. 2. Applied surface patterns by laser application 2021, vol. 72, no. 4 


\begin{tabular}{|c|c|c|c|c|}
\hline Aesthetic Design & Physical Design & Weaving Production & Laser Application & $\begin{array}{l}\text { Measurement of } \\
\text { Structural Parameters }\end{array}$ \\
\hline $\begin{array}{l}\text { - Determination of } 12 \\
\text { different surface } \\
\text { design } \\
\text { - Determination of } \\
\text { weave units of } \\
\text { designs for } \\
\text { weaving } \\
\text { - Creating of surface } \\
\text { patterns by using } \\
\text { weave units for } \\
\text { laser application }\end{array}$ & $\begin{array}{l}\text { - Determination of } \\
\text { structural parameters } \\
\text { of fabrics: } \\
\text {-\%100 cotton-carded } \\
\text { yarns } \\
\text { - Warp: } 30 \text { tex; indigo } \\
\text { dyed } \\
\text { - Weft: } 27 \text { tex; non-dyed } \\
\text { - Determination of } \\
\text { theoretical settings by } \\
\text { Ashenhurst formula } \\
\text { - Determination of } \\
\text { theoretical mass per } \\
\text { unit area } \\
\text { - Re-arrangement of } \\
\text { settings according to } \\
\text { limitations }\end{array}$ & $\begin{array}{l}\text { - Production of } 12 \\
\text { denim fabrics having } \\
\text { different surface } \\
\text { designs } \\
\text { - Production of a } \\
\text { classical denim fabric } \\
\text { having } 3 / 1 \text { twill weave }\end{array}$ & $\begin{array}{l}\text {-12 different surface } \\
\text { designs marked on } \\
\text { the surface of } \\
\text { classical denim } \\
\text { fabric } \\
\text { - Handling surface } \\
\text { designs similar to } \\
\text { weaving } \\
\text { technology }\end{array}$ & $\begin{array}{l}\text { - Determination of } \\
\text { settings and mass per } \\
\text { unit area of woven } \\
\text { fabrics } \\
\text { - Comparison of } \\
\text { theoretical, re- } \\
\text { arranged and } \\
\text { measured results }\end{array}$ \\
\hline
\end{tabular}

Fig. 3. Design, production and evaluation steps of the study

There could be some technical limitations in the physical design stage of the fabric. In this study, fabrics were woven on $\mathrm{CCl}$ dobby sampling loom and the count of used reed on the machine $\left(R_{n}\right)$ was 100 . Therefore, the production parameters were changed according to this reed count and a certain setting reduction ratio was applied to the theoretically calculated warp and weft setting of designed fabrics. Besides, a classic 3/1 twill denim fabric was also produced in order to apply the surface designs by laser technology. The weave factor of $3 / 1$ twill weave is 0.67 in both warp and weft directions.

In figure 3, the design, production and evaluation steps of this study are summarized.

\section{RESULTS AND DISCUSSION}

Theoretically calculated results of settings and mass per unit area of finished fabric by using equations 1-3 are given in table 1 . It can be observed that the weave factor, namely the weave type, affects the settings. In the study, there was a technical limitation at the weaving production because of used weaving reed. Therefore, the loom setting of the fabrics was re-designed as 30 threads/cm along warp direction and the warp setting of finished fabrics was estimated as being 32 threads/cm according to the supposed crimp factor. It can be assumed that a setting reduction between the ranges of $5-21 \%$ was applied for the theoretically calculated settings according to weave type. However, the break of warp yarns was higher during the weaving operation with 32 threads/ $\mathrm{cm}$ warp setting and 29 threads/cm weft setting.

Therefore, the weft setting of produced fabrics was decreased to decrease the tension on the warps and rearranged weft setting at was defined as being 20 threads/cm.

Setting and mass per unit area measurements of woven fabrics were done at standard atmospheric conditions. As seen in table 1, the measured warp settings are different from theoretically calculated ones. But after settings were rearranged according to the limitations such as used reed and breaking problem of warp estimated values were similar to measured ones. The mass per unit area of finished fabrics was lower than the theoretically calculated ones. The structural parameters of classical denim fabric having 3/1 twill weave were measured as 32 threads/ $\mathrm{cm}$ warp setting, 20 threads/cm weft setting and $176.43 \mathrm{~g} / \mathrm{m}^{2}$ mass per unit area.

Table 1

\begin{tabular}{|c|c|c|c|c|c|c|c|c|c|}
\hline \multicolumn{10}{|c|}{$\begin{array}{c}\text { THEORETICALLY CALCULATED, REARRANGED AND MEASURED STRUCTURAL PARAMETERS } \\
\text { OF THE FINISHED FABRICS }\end{array}$} \\
\hline \multirow[b]{2}{*}{$\begin{array}{l}\text { Design } \\
\text { code }\end{array}$} & \multirow[b]{2}{*}{$\mathrm{F}_{\mathrm{w} 1}-\mathrm{F}_{\mathrm{w} 2}$} & \multicolumn{3}{|c|}{ Theoretically calculated results } & \multicolumn{2}{|c|}{ Rearranged setting } & \multicolumn{3}{|c|}{ Measured results } \\
\hline & & $\begin{array}{c}\mathrm{S}_{1} \\
\left(\mathrm{~cm}^{-1}\right)\end{array}$ & $\begin{array}{c}\mathrm{S}_{2} \\
\left(\mathrm{~cm}^{-1}\right)\end{array}$ & $\begin{array}{c}w \\
\left(g / m^{2}\right)\end{array}$ & $\begin{array}{c}\mathrm{S}_{1} \\
\left(\mathrm{~cm}^{-1}\right)\end{array}$ & $\begin{array}{c}\mathrm{S}_{2} \\
\left(\mathrm{~cm}^{-1}\right)\end{array}$ & $\begin{array}{c}\mathrm{S}_{1} \\
\left(\mathrm{~cm}^{-1}\right)\end{array}$ & $\begin{array}{c}\mathrm{S}_{2} \\
\left(\mathrm{~cm}^{-1}\right)\end{array}$ & $\begin{array}{c}w \\
\left(g / m^{2}\right)\end{array}$ \\
\hline D1 & $0.67-0.67$ & 34 & 30 & 224.12 & 32 & 20 & 31 & 20 & 176.26 \\
\hline $\mathrm{D} 2$ & $0.72-0.72$ & 36 & 33 & 240.85 & 32 & 20 & 32 & 20 & 175.86 \\
\hline D3 & $0.72-0.72$ & 36 & 33 & 240.85 & 32 & 20 & 32 & 20 & 179.59 \\
\hline D4 & $0.80-0.80$ & 40 & 36 & 267.61 & 32 & 20 & 30 & 22 & 179.98 \\
\hline D5 & $0.67-0.67$ & 34 & 30 & 224.12 & 32 & 20 & 30 & 20 & 174.20 \\
\hline D6 & $0.80-0.80$ & 40 & 36 & 267.61 & 32 & 20 & 32 & 22 & 185.97 \\
\hline D7 & $0.67-0.67$ & 34 & 30 & 224.12 & 32 & 29 & 32 & 22 & 185.05 \\
\hline D8 & $0.67-0.67$ & 34 & 30 & 224.12 & 32 & 20 & 32 & 20 & 174.99 \\
\hline D9 & $0.67-0.67$ & 34 & 30 & 224.12 & 32 & 20 & 32 & 20 & 171.65 \\
\hline D10 & $0.75-0.67$ & 38 & 30 & 236.80 & 32 & 20 & 31 & 20 & 176.35 \\
\hline D11 & $0.67-0.57$ & 34 & 26 & 206.52 & 32 & 20 & 32 & 20 & 180.24 \\
\hline D12 & $0.75-0.67$ & 38 & 30 & 236.80 & 32 & 20 & 32 & 21 & 182.43 \\
\hline
\end{tabular}


In figure 4, examples for some surface view of designed denim fabrics obtained by weaving and laser technologies were given. Surface views obtained by two different techniques were very similar to each other. Only, D9 design could not be applied by the used laser machine. Because there are thinner lines on the patterns which could not be applied with the used laser beam.

Two production technologies have advantages and disadvantages when compared to each other. The surface designs were applied successfully by weaving technology. However, weaving technology is a long, stressful and costly process because of weaving preparation operations. Firstly, the design calculations for weaving should be done for each weave type in order to define settings and to estimate mass per unit area of the product. But these calculations are so complicated and take more time. Besides, the results to be revised for each weave type according to limitations on the production stage. The drafting plan of the complicated weave designs are also difficult and can cause some permanent faults on the fabric. The elimination of such faults required more cost due to labour and time. It was seen that designs obtained by weaving technology have a three-dimensional effect and the surface properties of all designs are different because of the long floatings of warp and weft yarns. These created different handle properties at all fabrics having different surface designs. The handle properties of fabrics produced by weaving technology were evaluated better. In this study, the mass per unit area and settings of all designed fabrics produced with weaving technology were different. On the other hand, as denoted in previous studies [13-19] surface designs are acquired in a shorter time and less labour by using laser technology. Laser technology is a computer-controlled process with a lower error rate [13-19]. Besides, surface designs can be applied to a classical denim fabric by using laser technology without the need for new design calculations. This means the production of a denim fabric having a surface pattern can be started in a shorter time. The structural parameters such as settings and mass per unit area of fabric are the same for all type of different surface designs created by laser technology. Although these structural parameters are different in each woven design. Besides, there can be some damage problems of laser technology applied to very light fabrics. Therefore, the machine parameters should be chosen well [13-15, $20,22,23]$. It is known that the performance properties such as strength properties decrease after laser treatment [18, 21, 24]. But surface patterns can be achieved successfully by weaving technology, without loss of strength.

Laser technology provides a more flexible working space for designers. The designer is unlimited in developing the pattern. However, weaving technology has some limitations about the weave capacity of the loom, especially in dobby looms. In this study, fabrics were woven with a maximum of 18 heald shafts including edges. Besides, the dimensions of patterns have limitations in weaving technology because of design capacity. However, the dimension of patterns can be changed in laser technology, so the design capacity is higher in this system [13, 17-20]. On the other hand, in this study, laser technology has limitations about applying very light lines on fabric surface which can be obtained with weaving technology by the floating of one or two threads. Consequently, in recent years, laser technology is popular in the fading of denim fabrics by having a huge design capacity and being a simpler and faster treatment. Comparing with other denim finishing treatments it is an eco-friendly production method because of being a dry treatment without the use of

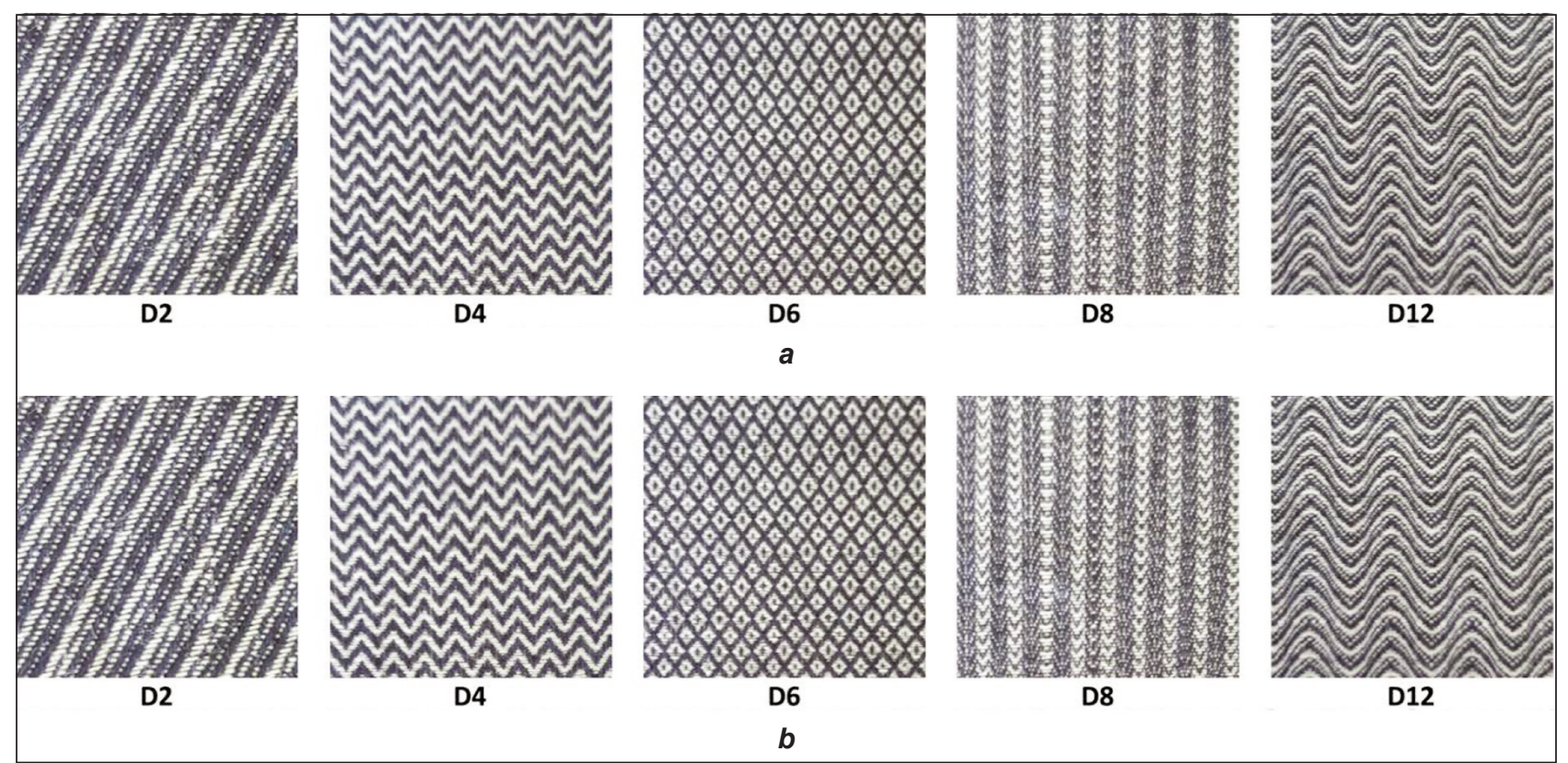

Fig. 4. Same design patterns applied by: $a$ - weaving technology; $b$ - laser technology 
water and chemical agents [13-16]. So, it can be preferred in the production of different surface designs.

\section{CONCLUSION}

In this study, a design study was carried out in order to design denim fabrics having different surface patterns. The contrast was the theme of aesthetic design studies. Designed surface patterns were produced by using two different technologies: weaving and laser. The design steps of these two technologies were explained in detail to compare these technologies. The surface views of the two techniques were found similar to each other. The structural parameters of different designs such as settings and mass per unit area were different for each fabric produced by weaving technology. On the other hand, all structural properties were the same for laser technology. The design and production processes of weaving technology were more complicated than laser treatment. The designs drawn on the computer screen easily created on the surface of the denim fabric by laser technology. Laser technology has advantageous in fast production, less error rate, less effort, higher design capacity, and great production. It is also an eco-friendly finishing process comparing with other denim fading processes. As a result, laser technology can be preferred as an efficient method for the surface design of denim fabrics. However, surface designs achieved by weaving technology have also advantages as both having no damage of fabric after production and having various surface properties because of different floatings. In further studies, it is aimed to compare the performance properties of denim fabrics produced by weaving and laser technology.

\section{REFERENCES}

[1] Tarhan, M., The Effect of Various Denim Fading Processes on the Performance Characteristics of Denim Goods, MSc Thesis, The Graduate School of Natural and Applied Sciences, Dokuz Eylül University, 2005

[2] Karagöz, G., During the processes of denim finishing resultant damages, the reason of damages and help possibility, MSc Thesis, Ege University, 2009

[3] Kaynak, H.K., Babaaslan, O., Avcı, M.E., Doğan, F.B., Effects of spinning technology on denim fabric performance In: Industria Textila, 2017, 68, 3, 197-203, https://doi.org/10.35530/IT.068.03.1336

[4] Özdemir, D., Research on alternative processes for the bleaching of denim garments by sodium hypochlorite and potassium permanganate, MSc Thesis, Ege University, 2006

[5] Paul, R., Denim and jeans: an overview, In: Denim: Manufacture, Finishing, and Applications, Edited by Roshan, P., Cambridge: Woodhead Publishing, 2015, 1-11

[6] Jucienè, M., Dobilaitè, V., Kazlauskaitè, G., Influence of industrial washing on denim properties, In: Materials Science, 2006, 12, 4, 355-359

[7] Dekanića, T., Pušić, T., Soljačić, I., Influence of special finishes on denim properties, In: Indian Journal of Fibre \& Textile Research, 2015, 40, 170-174

[8] Pazarlioğlu, N.K., Sariisik, M., Telefoncu, M., Treating denim fabrics with immobilized commercial celluloses, In: Process Biochemistry, 2005, 40, 767-771

[9] Sariisik, M., Use of cellulases and their effects on denim fabric properties, In: AATCC Review, 2004, 4, 1, 24-29

[10] Montazer, M., Maryan, A.S., Influences of different enzymatic treatment on denim garment, In: Applied Biochemistry and Biotechnology, 2010, 160, 2114-2128

[11] Kan, C.W., Yuen, C.W.M., Wong, W.Y., Optimizing color fading effect of cotton denim fabric by enzyme treatment, In: Journal of Applied Polymer Science, 2011, 120, 3596-3603

[12] Sülar, V. Kaplan, S., Effects of different finishing processes on some performance characteristics of denim fabrics, In: Industria Textila, 2011, 62, 6, 283-288

[13] Kan, C.W., Yuen, C.W.M., Cheng, C.W., Technical study of the effect of $\mathrm{CO}_{2}$ laser surface engraving on the colour properties of denim fabric, In: Coloration Technology, 2010, 126, 365-371

[14] Dascalu, T., Acosta-Ortiz, S.E., Ortiz-Morales, M., Compean, I., Removal of the indigo color by laser beam-denim interaction, In: Optics and Lasers in Engineering, 2000, 34, 179-189

[15] Kan, C.W., $\mathrm{CO}_{2}$ laser treatment as a clean process for treating denim fabric, In: Journal of Cleaner Production, 2014, 66, 624-631

[16] Stoyanov, B.T., Drumev, K.I., Genov, D.N., Fashion design using laser engraving technology, In: Journal of the Technical University of Gabrovo, 2016, 52, 53-57

[17] Khalil, E., Sustainable and ecological finishing technology for denim jeans, In: AASCIT Communications, 2015, 2, 5,159

[18] Ondogan, Z., Pamuk, O., Ondagan, E.N., Ozguney, A., Improving the appearance of all textile products from clothing to home textile using laser technology, In: Optics and Laser Technology, 2005, 37, 631-637

[19] Nayak, R., Padhye, R., The use of laser in garment manufacturing: an overview, In: Fashion and Textiles, 2016, 3, $5,1-16$ 
[20] Yuan, G., Jiang, S., Newton, E., Fan, J, Au, W., Application of laser treatment for fashion design, In: Journal of the Textile Institute, 2012, 103, 1, 48-54

[21] Tarhan, M., Sariisik, M., A comparison among performance characteristics of various denim fading processes, In: Textile Research Journal, 2009, 79, 4, 301-309

[22] Juciene, M., Urbelis, V., Juchneviciene, Z., Cepukone, L., The effect of laser technological parameters on the color and structure of denim fabric, In: Textile Research Journal, 2014, 84, 6, 662-670

[23] Kan, C.W., Colour fading effect of indigo-dyed cotton denim fabric by $\mathrm{CO}_{2}$ laser, In: Fibers and Polymers, 2014, $15,2,426-429$

[24] Moralesa, M.O., Poterasua, M., Ortiza, S.E.A., Compeana, I., Alvaradob, M.R.H., A comparison between characteristics of various laser-based denim-fading processes, In: Optics and Lasers in Engineering, 2003, 39, $15-24$

[25] Ozgüney, A.T., The comparison of laser surface designing and pigment printing methods for the product quality, In: Optics and Laser Technology, 2007, 3, 5, 1054-1058

[26] Başer, G., Engineering approach to industrial design of woven fabrics, In: International Journal of Fashion Design, Technology and Education, 2008, 1, 2, 79-87

\section{Authors:}

BEFRU R. BÜYÜKBAYRAKTAR ${ }^{1}$, GÜLCAN ERCIVAN BATUR ${ }^{2}$

${ }^{1}$ Dokuz Eylul University, Engineering Faculty, Textile Engineering Department, Tınaztepe Kampüsü, 35397, İzmir, Turkey

2Dokuz Eylul University, Fine art Faculty, Textile Fashion Design Department, Tınaztepe Kampüsü, 35397, İzmir, Turkey, e-mail: batur.gulcan@gmail.com

\section{Corresponding author:}

BEFRU R. BÜYÜKBAYRAKTAR

e-mail: befru.buyukbayraktar@deu.edu.tr 